\title{
Behind the beer: An examination of 'entrepreneurial' motives for starting a craft brewery
}

\author{
Vaughan Ellis \& James Richards ${ }^{1}$
}

\author{
Vaughan Ellis, Edinburgh Napier University \\ v.ellis@napier.ac.uk \\ James Richards (Heriot Watt University) \\ j.richards@hw.ac.uk
}

Vaughan Ellis is a Lecturer in Labour Relations at Edinburgh Napier University. Vaughan has previously been published in international quality journals and edited book collections with his research examining the transformation of clerical work, the experience of call centre work and trade unions. His present research interests include the emerging craft beer sector within Scotland with a particular focus on job quality. His favourite pint is Pale Ale (Cascade) by NewBarns of Leith, Edinburgh.

James Richards is an Associate Professor in Human Resource Management at Heriot-Watt University, Edinburgh, and an Academic Member of the Chartered Institute of Personnel and Development. James has published research in human resource management and employee relations journals, edited book collections and consultancy-based reports. James' current research interests include hidden disability and the workplace, in-work poverty, sustainable working lives, Leaveism and the Trade Union Act 2016. His favourite pint is Citra T40 by Oakham Ales of Peterborough.

\footnotetext{
${ }^{1}$ The authors would also like to acknowledge the input of Jennifer O'Neil (Edinburgh Napier University) who assisted with data collection
} 


\section{ABSTRACT:}

Brewing has experienced a considerable revival in recent years with the number of brewers in the UK being at its highest level since the 1930s (Cask Report, 2018). After decades of mergers and takeovers saw the emergence of a small number of global brewing conglomerates, many of the recently established brewers have spearheaded what has been referred to as a 'craft beer revolution'. Typically, producing small batches of artisan brews and with small workforces, the output of craft brewers accounts for approximately $2.5 \%$ of all beer sales in the UK, but is the fastest growing sector of the drinks market. The growth of the industry mirrors that seen by artisan food producers and has led some to suggest an emerging preference for rejecting mass produced food and drink products.

Despite recognition of the craft beer industry's emergence, growth and cultural significance, almost nothing is known about the individuals who started these new breweries, nor what their motivations for doing so were. Drawing upon thirty in-depth, semi-structured interviews with owner-brewers of craft breweries from across Scotland, this chapter presents findings examining owners' backgrounds and motivations for starting their brewery. The findings show a range of motivations and expectations amongst the group of owners and provide a useful basis for making practical recommendations of how other aspiring craft beer 'entrepreneurs' can be best supported by the industry.

\section{KEYWORDS:}

1. micro breweries.

2. brewing entrepreneurs

3. craft beer

4. push and pull factors

5. craft work

6. career change 


\section{Introduction}

One of the most important developments within the brewing industry over the pasty decade has been the emergence of the craft beer sector. With significant numbers of new small, artisan breweries being formed, the UK now has more breweries than it has had since Victorian times. As noted throughout this volume though, despite the (re)emergence of this new sector, to date relatively little scholarly attention has been given to the phenomenon. Although studies do exist which consider the cultural significance of craft beer (Thurnell-Read, 2014; Wallace, 2019), specific national and regional contexts (c.f. Dennett and Page, 2017; Fastigi et al, 2018), marketing strategies adopted by breweries (Williams et al, 2018) and gender identities (Rydzik and Ellis-Vowles, 2018) to date, the individuals who choose to create them and their reasons for doing so have been neglected. Gaining a better understanding of the profiles of those who have founded a craft brewery, their motivations for doing so and experiences of having done it, can assist in the development of more effective support for nascent businesses as well as making a more general contribution to our broader understanding of the sector. As typically very small entities, and in many cases sole traders, the experience, attitude, commitment and nature of the individuals who start them are likely to have a disproportionately high effect on the sustainability and thus longevity of craft breweries. For both socio-cultural and economic reasons therefore, it is important to better understand the backgrounds, motivations and experiences of this cadre of brewing entrepreneurs in order to assess how they can be better supported. Afterall, for lovers of craft beer and those who support the broader artisanal food and drink movement it is important that these fledgling organisations survive.

This chapter tells the stories of a group of owner-brewers who became part of this craft beer movement by establishing their own breweries across Scotland. In doing so, the chapter seeks to answer two questions (i) who are the people who start craft breweries? And (ii) why do they do it? The chapter examines the individuals' back stories, considers their motivations for establishing a craft brewery and the meanings that they derive from their work. The chapter is organised into five sections with an overview of relevant literature covered in the next section. Following this an overview of the methodology adopted in collecting, analysing and presenting data is provided. The research findings are then presented and discussed with the chapter ending by drawing some conclusions.

\section{The business of brewing}

The histories of beer, breweries and human development have been inextricably linked for millennia. Between 9000 and $7000 \mathrm{BC}$ in several locations around the world humans began the transition from a nomadic life (an extractive economy) to a settled one as farmers (an agrarian economy) (Swinnen and Briski, 2017). This change saw the development of civilization, community and prosperity not possible through the less efficient nomadic lifestyle. Archaeologists found what are believed to be the earliest evidence of beer production, clay tablets recording a recipe for making beer and dated to 6000 BC, in 'Uruk', Mesopotamia, the cradle of civilization between the Tigres and Euphrates rivers (ibid.). The Egyptian dynasties and the Sumerians also left considerable evidence of brewing in the archaeological record. In such civilisations beer production was an essential industry ensuring sufficient production of a comparatively safe drink, a gift for the gods during religious festivals and a 
commodity to export for economic and political gain. Brewers, and their breweries, were often venerated and embodied as Gods within many societies².

During the formative stages of beer production, brewing, in most cases involved multiple small scale operations under the direction of skilled master brewers. In the UK, this tradition largely held right up until the industrial revolution in the eighteenth century. Although it was the Romans who had initially brought the idea of a 'pub' to Britain it was not until the middle ages that they sold beer, often made by a brew mistress on the premises (Wolfe, 2016) and more latterly from 'common brewers', operations producing larger volumes of beer for retail to numerous 'pubs' (Pearson, 2010). The industrial revolution, based largely on scientific and engineering advancements producing new technologies, the emergence of the factory system of production and significant relocation of populations to emerging cities such as London, Birmingham, Manchester and Glasgow, led not only to significant increases in the demand for beer from thirsty manual workers, but also a fundamental transformation in the nature of the brewing process and models of ownership. With the greater application of technology, scientific advances and significant increases in scale of brewing volumes the once venerated master brewer increasingly became proletarianized due to industrialization commodifying their skills and separating much of the conception and execution of brewing. As in many other industries, increasingly, clerks and brewery managers took responsibility for planning brewery operations and controlling costs, as work was deskilled and cheapened (Braverman, 1974). In the industrialised brewery, ownership was typically distributed amongst shareholders, rather than held by an individual, and maximising profits rather than quality of beer became the goal (Swinnen and Briski, 2017).

The industrialization of beer production in eighteenth century Britain and the effect this had on profitability of breweries resulted in larger breweries and over time a concentration within the brewing industry as smaller brewhouses were unable to compete on price and reliability of production. By 1860 brewhouses only accounted for $10 \%$ of beer production in the UK and only in Birmingham did they hold onto a significant volume of retail trade (Pearson, 2010). In contrast, commercial brewing output in Burton upon Trent alone trebled in size every ten years between 1850 and 1880 (Gourvish and Wilson, 1994). This concentration of brewing continued apace throughout the twentieth century and soon became a global phenomenon with mergers and takeovers of breweries around the world. This trend reached its zenith with the creation of $A B \operatorname{InBev}-S A B M i l l e r$ on $10^{\text {th }}$ October 2016 resulting in the world's first truly global brewing conglomerate with operations in almost every major beer market, '...earning half of the total global beer profits and producing one in every three pints of beer sold worldwide' (Swinnen and Briski, 2017: 63). In the commodification of beer the craft of the brewer became a largely forgotten, and no doubt for many irrelevant story. In essence, brewers became disassociated, and alienated from the beer they produced.

However, this tendency of centralisation and the dominance of mass produced and for many, bland tasting beer has not been without some resistance from consumers, skilled brewers and homebrewers alike. Although with its origins in the 1970s with the formation of the Campaign for Real Ale

\footnotetext{
${ }^{2}$ The most notable of these deities was Ninkasi, a Sumerian goddess of brewing who it was believed gave beer to the world and was also the brewer to the gods (Gately, 2008). Dating from around $4000 \mathrm{BC}$ she is the oldest of the many beer gods from ancient civilisations around the world.
} 
(CAMRA) in the UK and provision of tax relief for smaller brewers in the USA (Tremblay and Tremblay, 2005; Hindy, 2014), a move mirrored in the UK in 2002, meaning small batch brewing was theoretically economically viable, the 'craft beer' movement emerged. Seen by many (c.f. Sennett, 2008; ThurnellRead, 2014; Brown, 2020) as allied with a broader societal rejection of mass produced goods, produced under Tayloristic (Taylor, 1911) working conditions, the craft beer sector has enjoyed impressive growth over the past decade across the world. As discussed throughout this volume craft beers are artisan brews, typically made in small batches by small breweries often controlled and owned by brewers themselves, come in a diverse range of styles and take advantage of the wide array of new hop varieties to produce taste profiles lacking in 'manufactured beers'. Seen as an economic, cultural and social phenomenon the 'craft beer counter revolution' (Swinnen and Briski, 2017) returns the owner-brewer to the story of brewing.

When seeking to better understand the motivations of those who have started a craft brewery a number of contributions from entrepreneurial studies provide a basis for developing a conceptual framework for doing so. Many of these studies have attempted to classify entrepreneurial types and others have linked 'types' of entrepreneurs with economic outcomes in order to predict likely longterm success for their businesses (Berthold and Neumann, 2008; De Martino and Barbato, 2003; Shinnar and Young, 2008). Understandably, given the discipline, many of these studies are grounded in a specifically econometric view of the entrepreneur, a value creator and innovator driving economic success by challenging and disrupting existing markets and creating new ones. As Swan and Morgan (2016: 121) note many call upon Schumpeter's (1934) theory of economic development which argued entrepreneurial activity was key to economic success as it '...provided new income sources and generated employment through reorganization or better utilization of resources.' Indeed, this stereotype of the entrepreneur as a risk-taker, profit-maximiser and driver of economic success has been well entrenched within UK economic policy since the election of the first Thatcher government in 1979 which saw them as important agents in 'transforming' the UK economy. As Thurnell-Read (2021) presciently noted such a stereotype is still evident amongst politicians, academics, the media and entrepreneurs themselves.

\section{Identifying entrepreneurial types}

Literature typically identifies two broad types of factors which motivate entrepreneurs to create a business (Hakim, 1989; Segal et al, 2005). Firstly, 'pull' or 'positive' factors are those that attract people to starting a business, such as seeing a market opportunity to meet a demand or to make a profit. 'Push' or 'negative' factors are those personal or external factors, such as loss of employment or dissatisfaction with current employment (Cromie, 1987). Such a binary approach to understanding motivations is commonly used within entrepreneurship literature with 'pull' factors having been found to be more prevalent (Sagal et al, 2005). 'Pull' factors are taken as examples of voluntary entrepreneurship (Gilad and Levine, 1986) and 'push' factors as necessity entrepreneurship (Hessels et al, 2008).

Others, in seeking to better understand these broad motivation types have added additional factors. In particular, Kirkwood and Walton (2010: 208) concluded that 'motivations for entrepreneurship can be seen to revolve around four main drivers: a desire for independence; monetary motivations; factors related to family and factors related to work.' The first two of these main drivers are typically classified 
as 'pull' or 'positive' factors and the latter two, 'push' or 'negative' factors. The important contribution though by Kirkwood and Walton (ibid) was to highlight lifestyle/family entrepreneurship as a generic motivation. Similarly a desire for greater autonomy (Borooah et al., 1997) or flexibility (Gatewood et al., 1995; Feldman and Bolino, 2000) have been reported by other researchers.

Interestingly, when assessing the extent to which monetary gain was a significant motivator for entrepreneurial decisions to start businesses research has concluded that money making typically ranks lower in motivations of entrepreneurs than other factors (Kirkwood and Walton, 2010) and particularly so amongst women (Taylor and Newcomer, 2005). Indeed, internal motivations for greater autonomy or independence (Gatewood et al 1995, Cassar, 2007) and greater work-life balance (Hughes, 2003) have been found to be greater drivers for starting a business. A more subtle reading of relevant literature then, recognises both the definitional ambiguity of the term 'entrepreneur' and the diversity of motivations for starting businesses, which extend beyond pure economic criteria (Baumol, 1990). In particular, recent literature highlights social (Dacin et al, 2010), sustainability (Dean and McMullen, 2007) and lifestyle objectives (Getz and Carlsen, 2000; Shaw and Williams, 2004) amongst entrepreneurs.

Empirical research into entrepreneurial motivations recognises that people typically start businesses because they want to and not due to a lack of alternative options, nor because they had identified a stellar business opportunity (Hughes, 2006). Instead, pragmatic concerns for greater flexibility and control over their working lives appear to dominate. It is clear though that a range of motivations exists and that their relative importance to particular entrepreneurs is uncertain. Furthermore, a noticeable feature of much of the literature reviewed above though is the reliance on abstracted empiricism as a means of deducing meaning. A near fetishisation of hypothesis testing, large scale surveys and correlations has largely removed the individual entrepreneur from the study of entrepreneurship. Although perhaps offering some intuitive means of classifying entrepreneurial motivations, such an approach collapses difference, suggests general applicability regardless of context, potentially downplays the variance of motivations, perceives human behaviour as being predictable and in privileging economic rather than personal perspectives on entrepreneurship, loses the human story behind such decisions. Concurring with Kirkwood and Walton (2010: 206) this chapter argues that to understand the motives of those starting businesses '...we must view their decisions as being embedded in a wider sociological perspective.' In other words, greater knowledge of the individuals themselves, their backgrounds and life histories and the locations in which they live and work is needed as the social environment affects entrepreneurs (Hurley, 1999).

\section{Methodology}

There is value in now focusing upon matters of research design and execution. In doing so, the chapter aims to make a methodological contribution which will hopefully support subsequent research on craft breweries. The chapter will now therefore, provide an overview and justification of how the data presented here was collected and analysed. 
At the time of beginning the research project no definitive list of craft breweries existed. The first stage of research design therefore, involved creating a list of craft breweries within Scotland, the area that the study was to focus on. Although a number of lists of breweries did exist they contained different breweries so could not individually be relied upon to provide a definitive 'population' of craft breweries in Scotland. Instead, a new merged and verified list using a number of sources was produced by the research team. The Campaign for Real Ale's annually published 'Good Beer Guide' (GBG) (CAMRA, 2019) provides a useful list of breweries at the time of printing which includes information on location, contact details (including social media presence), brewery size and date of formation. This list was supplemented by reference to a website containing a map of breweries in Scotland, available at: https://brewedinscotland.co.uk/map/. The advantage of this source over the GBG was that it was regularly updated as new breweries were established and others closed. Finally, a search for 'craft breweries in Scotland' on Google, Facebook and Twitter was conducted to ensure that no breweries had been missed.

Having produced a list of 130 craft breweries $^{3}$ operating in Scotland the decision was made to invite all of them to participate in the study. The reasoning here was given the absence of any existing research examining who the founders of craft breweries were and why they started one, along with having the resources to visit all 130 breweries if required ${ }^{4}$, maximum breadth and depth of data collection should be the aim. Involving as many different breweries as possible provides the best opportunity to understand craft brewery owners as individuals and to discover their variety of motivations for starting a brewery. An information sheet providing details of the study's aims was created and issued to all breweries by email, post or through a 'contact us' webform on their webpage. To further aid recruitment of participants a Twitter account (@behind_thebeer) was established along with a blog (https://behind-the-beer.co.uk/) upon which details of the project aims and updates on progress were posted. The twitter feed was also used to re-tweet posts from the breweries the project was targeting to participate in the study along with general news stories about the industry. All craft breweries in Scotland with a twitter feed were 'followed' and as is the tradition, most 'followed back'. The twitter presence was an attempt to gain some sort of 'insider status' to build credibility and increase numbers of participating breweries. After initial requests for participation through letters, emails and web contact had stopped yielding new participants 'tweets' were sent to all breweries who had yet to respond. Finally as a last push for participants, postcards and beer mats with details of the project were produced and sent to all breweries yet to respond to earlier requests to participate (See Figure 1). The combination of methods used, as well as a persistent approach, led to 30 breweries agreeing to participate, approximately $23 \%$ of the population. Of all the methods used to recruit participants it is worthwhile noting that the use of twitter and the production of beer mats were the most effective.

Figure 1 here

\footnotetext{
${ }^{3}$ Craft breweries were defined as those producing less than 60,000 hectolitres of beer p.a.

${ }^{4}$ The study was funded by an Edinburgh Napier University Research grant
} 
As outlined earlier understanding of the motives of those who have started craft breweries is very limited. As such, a qualitative research approach was considered to be most appropriate to address the chapter's research questions as qualitative research approaches are well suited for studies examining under theorized questions (Edmondson and McManus, 2007). Data presented in this chapter was collected from 30 In-depth, semi structured interviews with owners of craft breweries conducted between June 2018 and February 2019. Interviews typically lasted between 80 and 120 minutes, were recorded and verbatim transcripts produced. Participating breweries were drawn from across Scotland with the furthest south being in the Borders and the most northernly in Elgin. Breweries ranged from having been formed a few months prior to the interviews to having been operating for longer than a decade. Copies of transcripts were sent to participants for verification and where necessary, clarification.

These transcripts were then thematically analysed using Miles and Huberman's (1994) five step process in which discrete thoughts on transcripts led to codes being identified and attached to relevant sentences and paragraphs of text. Relationships between codes were then identified and explanations for findings sought. So far as was possible, codes were allowed to emerge from the data itself rather than being imposed. As such analysis was approached from an interpretivist standpoint focusing on participants' understandings of events rather than relying on researchers' observations (Eriksson and Kovalainen, 2008). In contrast to much of the research on entrepreneurial motivations this study consciously sought to explore the phenomena through identifying contexts and linkages that explain events and behaviours (Dalenty, 2005, Willis et al, 2007). Given assurances of anonymity the names of breweries and their owners have been changed throughout this chapter.

\section{Findings}

The chapter now presents the research findings. This section is organised into two parts with the first examining the owner-brewers' backgrounds and the second, their motivations for starting a brewery. The first part of the section examines the professional backgrounds, ages, genders and levels of brewing experience at the point of starting their brewery in order to better understand the individuals themselves and to place the second part of this section in context. Through first understanding the owners' backgrounds, their motivations for starting their brewery can be better explained and theorised.

\section{Who are the owner-brewers?}

Perhaps the easiest place to start getting to know the owners is with the most recognisable characteristics, their ages and sex. Regarding the sex of participants, all but two owners were men. The age of owners had much greater variability though ranging from the youngest in his mid twenties to the oldest in his early sixties at the time of starting their brewery, with most being in their late forties or early fifties.

The majority of owners were University educated, had backgrounds in fields unrelated to brewing such as a research analyst, college lecturer and a property investor with engineers accounting for 
nearly $20 \%$ of owners. Most of the owners therefore, came from white collar professional and skilledmanual occupations. Many of these roles had allowed the owners to acquire a broad range of commercial skills such as project planning, finances, marketing and leading businesses. A notable feature of participants was that around half had held senior positions including Directorships and Managing Director roles. A number had been exposed to planned management development programmes during their careers which had seen them move between firms, organisational functions and in some cases national contexts.

For one of the owners, though, their previous career was an unusual one for sure and not one that obviously brought any transferable skills for founding a craft brewery:

I left the RAF in 2009 and went to work for a French Defence company who have a contract to provide Tornado simulator training so I'm an ex-Tornado pilot. I flew that jet for about ten years and a couple of others whilst I was in but ended up flying with the Dam Buster squadron (James, Towser Brewery).

However, around $20 \%$ of the brewery owners previously had related careers with a number having scientific backgrounds, some of which would prove useful in their new jobs:

I did science as a career so I did cover a bit of brewing when I was doing microbiology at University.... I did a PhD in microbiology and then came up to Dundee twenty years ago and worked in an agricultural research institute (Steve, Mod Brewery).

For some of these scientists, their degrees had built upon an earlier interest in home brewing with one owner having made his first brew as a teenager:

I'm a trained chemist, trained at University. I have always been a hobbyist in terms of brewing and my first beer I think I brewed I was thirteen with my Dad in the garden shed and it was awful stuff! (Johnny, Canary Brew)

Only just under $10 \%$ of owners had experience of working in the brewing industry, and not all of those had brewing experience, with some having worked in administration or management roles. However, a small majority of owners did have experience of home-brewing at the point of starting their breweries, although levels of experience differed greatly. For a minority home brewing had been a long term passion, such as Johnny from Canary Brew and Simon (below):

I probably started brewing around about 1980 when I started brewing home brew kits from malt extract. Then I found a book 'brewing beers liker those that you buy' and it was the first time I had seen recipes for whole grain beer and how to fake up your own kit to actually produce a grain beer. So from there, I just brewed more or less as a hobby for 25, 30 years up until around 2014 where I applied for a job in a local brewery (Simon, Garage Brewery). 
For most with home-brewing experience though, the hobby was a relatively new pursuit and they described their experience as 'limited' at the point of starting a brewery. A small number of the home brewers also possessed general 'handy-man' skills such as electrics and plumbing which they had either developed or enhanced through brewing. However, four owners had never brewed beer themselves and haven't since starting the brewery and two of these did not possess any kind of manual skills. For these owners their other skills and experiences gained in their careers were emphasized.

Around $30 \%$ of the home-brewers had attended formal brewing courses, with BrewLab four day courses in the North of England proving most popular. For these owners brewing was a science that needed to be learnt and importance was placed on understanding the principles as well as practicalities of brewing.

I did a brewing course at Brew Lab for a little while which was invaluable...but it's a bit like passing your driving test, you actually start to learn how to brew after you have finished, after you have got your qualification (Tom, Village Brewery).

For the rest though, they described themselves as self taught, relying on books and internet research to learn the process of brewing. All of the home-brewers emphasized the continuous learning by trial and error that home-brewing afforded them as well as the support of others. Whether it be through networks of other home brewers or from friends who were professional brewers, their brewing knowledge was continuously acquired through collaboration with others and trial at error at home.

Finally, it is important to note that only one of the owners described themselves as independently wealthy. Although a number had had senior management careers and were by no means suffering financial hardship at the time of starting their breweries, most had limited savings to be drawn upon. Indeed, nearly all of the owners were keen to emphasise the relatively low levels of capital that was required to start their brewery.

Why did they start a brewery?

Given their varied backgrounds it is perhaps unsurprising that the owners had a variety of reasons for starting a brewery. The three main reasons given by owners though were encouragement from friends/families, to provide a more fulfilling work-life and because they saw a business opportunity. For many, the decision was described as 'accidental' rather than 'planned' with a number emphasizing that owning a brewery was never part of their life plan but rather it just happened. Furthermore, there was often more than one reason why they started a brewery with motivations being a complex mixture of factors.

For those who acted upon encouragement of friends and family all were existing home brewers. The journey towards establishing a brewery typically started with receiving positive feedback on the quality of their home brew or an offer from their local pub to stock their beer if they could guarantee supply: 


\begin{abstract}
After I had been home brewing for about a year or so I got talking to the landlord of the local pub and I didn't know at the time but he had been interested in getting some local beer. He said to me one night 'so how's the brewing going' and as it was the end of the night so I was probably a few pints in I joked 'it's better than the crap you sell, l'll bring you some'. I gave him some beer and the next time I saw him he said to me 'you know if you ever want to put that in the pub l'd be happy to sell it. I just went away and thought, hmmm Maybe I should. I mean its pure ego and just for the laugh, how cool would it be to have your own beers selling in the local pub! (Sam, Garden Brew)
\end{abstract}

Many of the home brewers felt confident about their beer making abilities but had never believed it feasible to establish a brewery. Given that the brewing industry had become so concentrated within Scotland, as it had across the UK as a whole, perceptions of the minimum size of brewery required and the high start up costs were powerful barriers to entry. So many of the owners talked about the impact visiting other craft breweries, as customers on brewery tours, both in the UK and overseas, most notably the USA had upon them. Seeing the small size of many of these operations and often having the opportunity to discuss with those owners how they had established their breweries appears to have been a significant stimulus to realizing that doing the same was feasible. Many of the owners also emphasized the importance of early trail blazers such as BrewDog and other local breweries as providing inspiration to start their own. Seeing that others have done it and being able to connect with them was inspiring and acted as a proof of concept.

Two colleagues were returning to the States and wanted to set up a brewpub. They looked into touring around the local breweries here and I tagged along swearing I'd never start a brewery. I tagged along and saw that the kit that BrewDog, Cairngorm, Black Isle, Cromarty, the equipment these other local breweries were using was just a big version of what l'd already built in the garage. I guess that made it all very real and feasible (James, Towser Brewery).

Dissatisfaction with existing jobs provided the initial stimulus for a number of the owners to start a brewery. This was particularly the case amongst those from a scientific background. For these, brewing seemed a way to escape a career that they were no longer enjoying whilst still making the most of their existing skill set.

I didn't have the staying power in the industry (Chemistry) to get to where I wanted to be so I moved back to Moray. After brewing a beer for mum's birthday and being told 'that's really nice, you should start a brewery' a lightbulb goes on, the more research I do, the more I thought I could pull this off, so from the first idea to launch was eighteen months, not bad (Johnny, Canary Brew).

I've always been a consumer and coming from a science background where you are under contract and everything is laid on a plate, salaries, pensions etc. So it's a big challenge to move into being self employed....but for me, it was just doing something creative that I was after and I do enjoy drinking beer! (Steve, Mod Brewery) 
For others, particularly those in their fifties the prospect of starting a brewery afforded an opportunity to reshape their working life. No longer needing to focus on salary and promotion prospects to the same extent as when they were younger, starting a brewery was perceived to offer the chance for a better work-life balance. A number of the owners had set up their breweries either at home, in a garage or a shed or very near to home so avoided commuting. Able to plan brewing around other life commitments was seen as an attractive proposition and given their love of beer and brewing many commented that running a brewery did not feel like work, but rather a long holiday. The creativity afforded by brewing and the sense of ownership of a complete process was seen as bringing meaning to work, something that was attractive:

I get to hold the product and own quite literally the product from start to finish and you have something to show for your work at the end of the day. There is something very gratifying about that. At my stage of life, that was a very appealing thing for me. It seemed like a very rewarding way to pass some time and that I can do all of this around my other life responsibilities is the icing on the cake really (Sally, Kingdom Brewery).

Interestingly, very few owners stated that the decision to start their brewery was primarily motivated by recognizing a business opportunity. Although unsurprisingly most of the other owners did admit to assessing the business rationale for their brewery to a lesser extent. Most of these cited the lack of other breweries within their area and a sense that demand for craft beer was growing. For a handful of owners the decision to start the brewery though was as a result of identifying an opportunity to make money and as such the decision was a commercial one. Involving, detailed market research, assessment of strategic positioning, development of detailed business plans and clear objectives the brewery was there to compliment existing businesses that they owned. One of the owners, a property investor, spoke about having an opportunity to purchase some land in a fashionable part of their city and recognised an opportunity to use it for a brew pub, for that he needed a brewery. Another, needed to find a use for a former tractor showroom that he had inherited once his father had passed away and thought that a brewery would be an excellent way to showcase his firm's engineering abilities, as well as utilising a space. Finally, another inherited a farm when his father died which had a legacy brewery attached that had been losing money. In order to avoid a further drain on the family finances and seeing the potential to make the a profitable business, the brewery was relaunched. Inspired by trips to craft breweries in California, the owner saw the potential of mimicking these set ups in rural Scotland. With a strong focus on innovative beers and a rebranding of the business as a farm brewery the owner applied well developed business acumen to making the new brewery a commercial success. These owners had ambitious plans to gradually expand the size of the brewery operation, to employ more staff and to increase profits.

For the vast majority of the owners though adopting such a business focus and being driven by targets and objectives was an anathema for them and brought unwanted complexity and anxiety. Many of the owners talked about having little desire to grow the business from their present size given the additional costs and pressure to sell beer that this would bring. This was particularly true of those sole trader owners who were in their fifties at the time of starting the brewery. Of those who did wish to grow their brewery nearly all indicated that they wished to do so organically and only at a pace that could be funded by profits. The vast majority of the owners did not wish to undertake crowdfunding 
or to seek external financial support to fund expansion as they did not wish the additional stress that came with it. Indeed, the main motivation for wanting to expand the business was not the realization of greater profits for the sake of it but to make it possible to provide employment to others. A number of owners spoke at length about their pride in being rooted within a local economy and wanting to offer employment opportunities. This was particularly true of those owners whose breweries were based in rural locations and was the raison d'etre for one of them:

I had been involved in the community purchase of a wind turbine for the village, setting up a development trust for the sports centre and the community initiative in saving the local pub. We felt that the brewery should work in parallel with these developments. It's a small village with everyone knowing everyone and there was much enthusiasm about our project. So I came at it from a view of thinking about sustainability and trying to do things as locally as possible both in terms of employment and ingredients. We see the brewery as an opportunity to provide good local beer for the community and tourists alike whilst providing training opportunities for local people (Andrew, Village Brew).

It was clear as the owners spoke at length about the breweries and the journeys they had taken in forming and sustaining them the love and passion for what they did. Although the satisfaction of making and selling beer may not have been the founding motivation for all of the owners, it is what keeps them doing it. All of the owners spoke about the pleasure of creating beer and seeing others enjoying it. Many highlighted their pride in contributing to their local community, in many cases returning brewing to an area where it had long since disappeared. The brewery owners interviewed were a content lot, doing something they enjoyed.

When considering the significance and meaning of research findings it is first, worthy of note that none of the participants reported any scarce skills or specific work related experiences which they felt had been critical in successfully establishing a craft brewery. Indeed, the humility and candor of participants suggested that starting a craft brewery was an achievable goal for anybody who wanted to do so. A sense of learning 'what to do' and 'how to do it' whilst 'doing it' is writ large through the testimonies collected. Given, the relatively low costs of starting a craft brewery and at least for now, an expanding demand for craft beer, being a craft brewery owner is an accessible career choice for more people than may recognise it. Of course, this is not to diminish the pressures of running any kind of business or the high failure rate of small businesses in general, but a genuine sense of pleasure, pride and self-actualisation is offered by doing so.

Having discussed the backgrounds of the owners it is now important to return to the conceptual framework introduced earlier in the chapter in order to theorise, so far as is possible, the reasons for starting their breweries. Literature on entrepreneurial types and motivations provided a useful means to assess the meaning of findings discussed above. As such literature suggested would be the case the decision to start their breweries was a positive one rather than forced. Although motivated by a range of differing reasons including a search for a more fulfilling career, an extension of a home brewing interest with a push from friends and family or the rarer desire to take advantage of a business opportunity starting a brewery was something that ultimately all of the owners wanted to do. None were without other options at the time of doing so, whether that was remaining in existing jobs or 
starting alternative businesses. As such there were no 'necessity' entrepreneurs found amongst the owners who participated within this study.

However 'push' factors were commonly cited by owners. The desire to escape from unfulfilling jobs in other industries was particularly common. Many of these coming from a scientific background, and some who had home-brewing experience, saw the emergence of other trail blazing craft breweries as an opportunity to set up themselves. For these owners, their idea to establish a brewery was not sufficiently planned and strategised though to be classified as evidence of a 'pull' factor being the primary driver behind their choice. Each of these owners felt the push away from their existing roles more than the pull of an identifiable and specific business opportunity. Theirs was an idea that running a craft brewery was feasible and given relatively modest financial expectations from their businesses they took the plunge. Their approach can be contrasted with those few owners who did cite a response to a business opportunity as being the main motivator. The approaches taken by the two sets of owners differed, with greater planning and expectations the hallmark of those seeing the brewery as a commercial entity first and foremost.

The one 'pull' factor that was most commonly cited by owners was the desire for more flexibility and autonomy. Nearly all owners spoke about the attraction of greater control over their working lives and this is common amongst entrepreneurial motives for starting a business (Borooah et al., 1997; Feldman and Bolino, 2000; Gatewood et al., 1995). For some, the need to be able to work around family commitments was the driver whereas for others it was about avoiding unnecessary time wasting commuting. Given the range of ages of the owners no single reason for the attractiveness of flexibility other than a generalised desire to work to live, rather than live to work. For nearly all of the owners who were in effect 'lifestyle entrepreneurs' starting a craft brewery was driven by a desire for a better life.

It is important to note that many of the owners recognised the important and stimulating role played by others in giving them confidence that their desire for a more flexible life could also be a viable business. Visits to other breweries, informal support from other brewers as well as mentorship and guidance from Business Gateway and the Chamber of Commerce were all important enablers of realising their ambition. Indeed, the collaborative nature of the industry appears to be an important feature encouraging and sustaining nascent businesses. Existing breweries appear to play an important role therefore, in stimulating further creation of new breweries.

Finally, it is clear that most of the owners do not fit the stereotypical notions of an entrepreneur outlined by Schumpeter and extolled by politicians ever since. As others have found, financial motivations were the least significant motivation for starting their brewery. Indeed, by their own admission a number of the owners accepted that they weren't the greatest business people nor was profit what drove them. Instead, their passion for making good beer and the satisfaction derived from seeing others enjoy it was what drove them. Many felt fortunate to be able to at least cover life's essential expenses through making and selling beer. 


\section{Concluding comments}

This chapter sought to understand who the individuals who started craft breweries were and the reasons why they did so. In doing so, the backgrounds and experience of the owners were examined in order that their motivations could be better contextualized. The chapter has shown that there existed a variety of reasons for starting breweries with very few having much to do with making money. Instead, the brewery owners were typically looking for more meaning or greater flexibility and control from their working lives. In conclusion it is valuable to consider the implications of this study's findings for the craft beer industry.

Firstly, the vast majority of participants in this study had no previous involvement in the brewing industry and thus starting a brewery represented a change of career. Although some had previous careers in related fields many didn't, and most learnt as they went. To help maximise the likelihood of new craft breweries being successful in the long term, the industry would benefit from establishing a mentoring scheme. Such a scheme could pair new craft breweries with more established ones in order to enable transfer of learning and skill development. Industry bodies such as TBAS or SIBA would be well placed to facilitate such a scheme within their respective memberships. Alternatively, existing sources of State support for new businesses, such as Business Gateway or Princes Trust, could establish a scheme. The purpose, scope and longevity of the scheme is best determined by the industry, but the findings of this study suggest that there would be value in new or aspiring craft brewery owners having access to those who have faced the challenges of starting a new business in the industry. A significant number of this study's participants noted the important role played by others in assisting during the early stages of forming the business, and in particular helping provide confidence that successfully running a brewery was achievable.

Secondly, there would appear to be an opportunity for the industry to consider its approach to more formal training and development for brewery owners. Changing careers and transitioning to being a business owner requires the acquisition of new skills and although most appear to acquire sufficient proficiency to get by, a more considered and planned programme of training and development sessions may better support those owners who wish to thrive rather than just survive. Given the objective of TBAS to grow the economic contribution of craft breweries in Scotland over the coming decade and the value in having an industry specific programme, rather than relying on generic business skills training, they may be best placed and motivated to co-ordinate such a scheme.

Finally, there is a need for further research into the experiences of starting and running a craft brewery. A greater understanding of a wider group of owners than considered here, broadening the scope to include the rest of the UK and particularly the experiences of women would provide an even richer knowledge base from which to develop appropriate policy to support and develop this exciting sector which has done so much already to revitalise brewing in the UK. 


\section{References:}

Baumol, W.J. (1990). Entrepreneurship: productive, unproductive and destructive. Journal of Political Economy 98(5), 893-921

Berthold, N. and Neumann, M. (2008). The motivation of entrepreneurs: are employed managers and self-employed owners different?, Intereconomics, July/August, 236-44.

Borooah, V.K., Collins, G., Hart, M. and MacNabb, A. (1997). Women in business, in Deakins, D., Jennings, P. and Mason, C. (Eds), Women in Business, London: Paul Chapman Publishing.

Braverman, H. (1974). Labor and Monopoly Capital: The Degradation of Work in the Twentieth Century. New York: Monthly Press

Brown, P. (2020). Craft: An Argument. Why the term craft beer is completely undefinable, hopelessly misunderstood and absolutely essential, London: Storm Lantern Publications

Dacin, P. A., Dacin, M.T. and Matear, M. (2010). Social entrepreneurship: why we don't need a new theory and how we move forward from here. Academy of Management Perspectives 24(3): 37-57

Dean, T.J. and McMullen, J.S. (2007). Toward a theory of sustainable entrepreneurship: reducing environmental degradation through entrepreneurial action. Journal of Business Venturing, 22(1), 5076

Delanty G. (2005). Social Science. Berkshire: Open University Press.

DeMartino, R. and Barbato, R. (2003). Differences between women and men MBA entrepreneurs: exploring family flexibility and wealth creation as career motivators, Journal of Business Venturing, $18(6), 815-32$

Fastigi, M., Vigano, E., and Esposti, R. (2018). The italian microbrewing experience: features and perspectives, Bio-based and Applied Economics, 7(1), 59-86

Feldman, D.C. and Bolino, M.C. (2000). Career patterns of the self-employed: career motivations and career outcomes, Journal of Small Business Management, 38(3), 53-67

Gately, I. (2008). Drink: A cultural history of alcohol, New York: Penguin

Gatewood, E.J., Shaver, K.G. and Gartner, W.B. (1995). A longitudinal study of cognitive factors influencing start-up behaviours and success at venture creation, Journal of Business Venturing, 10(5), 371-91.

Getz, D. and Carlsen, J. (2000). Characteristics and goals of family owner-operated businesses in the rural tourism and hospitality sectors. Tourism Management 21(6), 547-560 
Gilad, B. and Levine, P. (1986). A behavioral model of entrepreneurial supply, Journal of Small Business Management, 24(4), 45-53

Gourvish, T. R. and Wilson, R. G. (1994). The British Brewing Industry 1830-1980, Cambridge: Cambridge University Press

Hakim, C. (1989). New recruits to self-employment in the 1980's, Employment Gazette, June, 286-97

Hessels, J., van Gelderen, M. and Thurik, A.R. (2008). Entrepreneurial aspirations, motivations and their drivers, Small Business Economics, 31(3), 323-39

Hindy, S. (2014). The Craft Beer Revolution: How a Band of Microbrewers is Transforming the World's Favorite Drink, New York: St Martin's Press

Hughes, K. (2006). Exploring motivation and success among Canadian women entrepreneurs, Journal of Small Business and Entrepreneurship, 19(2), 107-20

Hurley, A. (1999). Incorporating feminist theories into sociological theories of entrepreneurship, Women in Management Review, 14(2), 54-62

Kirkwood, J. (2004). One size doesn't fit all: gender differences in motivations for becoming an entrepreneur, unpublished PhD thesis, Department of Management, University of Otago, Dunedin

Kirkwood, J. and Walton, S. (2010). What motivates ecopreneurs to start businesses?, International Journal of Entrepreneurial Behaviour and Research, 16:3, 204-228

Miles, M.B. and Huberman, A.M. (1994.). An Expanded Sourcebook: Qualitative Data Analysis. California: SAGE

Pearson, L. (2010) Strategy for the Historic Industrial Environment: The Brewing Industry, A Report by the Brewery History Society for English Heritage, Available at: The Brewing Industry (historicengland.org.uk)

Rydzik, A. and Ellis-Vowles, V. (2018). Don't use the "weak word": Women brewers, identities and gendered territories of embodied work, Work, Employment and Society, 33(3), 483-499

Segal, G., Borgia, D. and Schoenfeld, J. (2005.) The motivation to become an entrepreneur, International Journal of Entrepreneurial Behaviour \& Research, 11(1), 42-57

Schumpeter, J.A. (1934). The Theory of Economic Development, Cambridge: Harvard University Press, Sennett, R. (2008). The Craftsman, London: Penguin

Shaw, G, Williams, A.M. and Greenwood, J. (1987). Tourism and the Economy of Cornwall. A Firm Level Study of Operating Characteristics and Employment, Exeter: University of Exeter 
Shinnar, R. and Young, C. (2008). Hispanic immigrant entrepreneurs in the Las Vegas metropolitan area: motivations for entry into and outcomes of self-employment, Journal of Small Business Management, 46(2), 242-62

Swan, C.D. and Morgan, D. (2016). Who wants to be an eco-entrepreneur? Identifying entrepreneurial types and practices in ecotourism businesses, The International Journal of Entrepreneurship and Innovation, 17(2), 120-132

Taylor, S.R. and Newcomer, J.D. (2005). Characteristics of women small business owners, in Fielden, S.L. and Davidson, M.J. (Eds), International Handbook of Women and Small Business Entrepreneurship, Edward Elgar Publishing, Cheltenham, 17-31

Swinnen, J. and Briski, D. (2017). Beeronomics: How beer explains the world, Oxford: OUP

Thurnell-Read, T., (2014). Craft, tangibility and affect at work in the microbrewery. Emotion, Space and Society, 13, 46-54

Thurnell-Read, T., (2021). Kindred spirits: Doing family through craft entrepreneurship, The Sociological Review, 69(1), 37-52

Tremblay, V.J. and Tremblay, C.H. (2005) The U.S. Brewing Industry: Data and Economic Analysis. Cambridge (MA): MIT Press

Unger, R. W. (2001). A history of brewing in Holland 900-1900: Economy, technology and the State, Brill Academic

Unger. R. W. (2004). Beer in the middle ages and the renaissance, University of Pennsylvania Press

Wallace, A. (2019). Brewing the truth: Craft beer, class and place in contemporary London, Sociology, 53(5), 951-966

Wolfe, W. (2016). Brewing Beer for Art, The Free Press. Kinston, North Carolina.

Williams, A., Atwal, G., and Bryson, D. (2018). Luxury craftsmanship - the emergent luxury beer market, British Food Journal, 121(2), 359-370

Willis, J., Jost, M. and Nilakanta, R. (2007). Foundations of Qualitative Research: Interpretive and Critical Approaches. Thousand Oaks: SAGE 
INSERT ANY TABLES / FIGS / PICTURES / ILLUSTRATIONS / TABLES HERE (or attach them in separate documents)

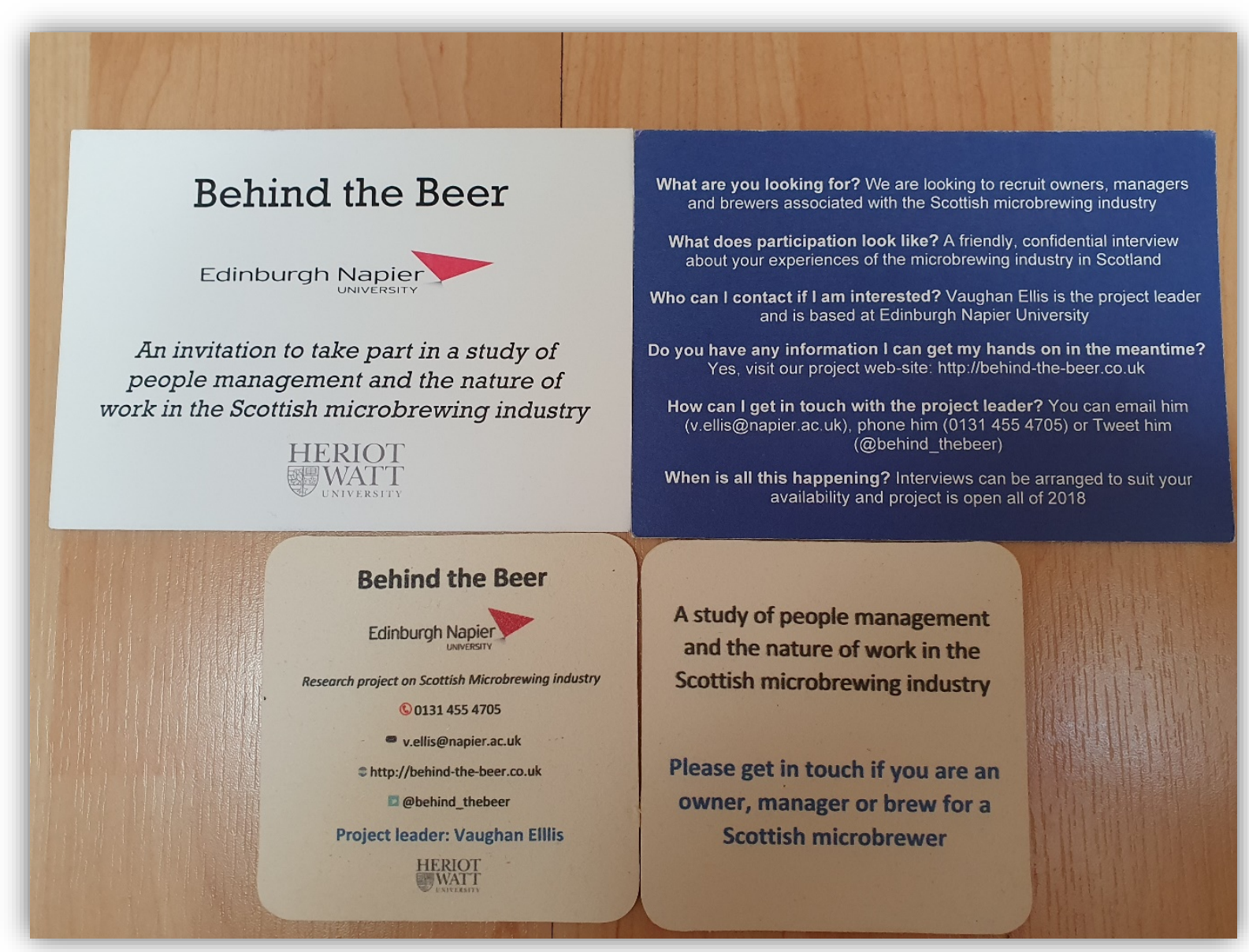

Figure 1 Postcard and Beer Mat used for recruitment of participant 